我マは以前より疎水相互作用に注目し蛋白 質の立体權浩の折れたたみについて研究してきた。 昨年の本学会においても報告したように製つかの 球状蛋白筫につ11て 折れたたみを行った結果 $X$

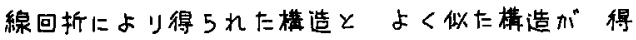
5 れている。

しかし及榙造を各むつラポドキシンの折れたた

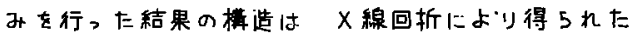
粗造とあまり似ていなれった。

そこで В楧贯における水素結合にも注目して 折れたたみを行いその結果を報告する。

蛋白筫の折れたたみは模造工ネルギーを最小化 することによって行う。模造エネルギーの最小化に 用い5 れる仮想蛋白算は棒成要素を主镍の部分 はN，C，O の各原子 側鎖の部分は之の体稓に 比例する体䅭を毛つ球乙近似し.变数志各践基の 主镍の二面角 $\varnothing . \psi$ 梳とをる。

考えるエネルギーは

(1)各愿子. 假铛球間の var der Waals O potential

(2)疎水基の側銷球間:踈水相互作用 $の$ potential

(3)ß-strand である領域の主鎖のアミド基・クルボ
ニル基間に水膟結合の potential

(4) S-S 結合 $\sigma$ potential

である。

满透エネルギーの最小化には蛋白算がうこダ

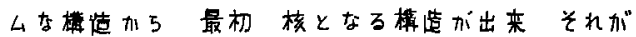
成長して島となり島が成長・虽合して その国有 方立体櫵造へと折れたたんで巾くという輪湖・彥 费の息模型を適応する。

そこで 構造エネルギーの最小化を行う初期扰態ま 核ガ出来上ったものを考えその核として二次橉

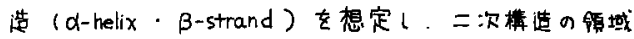

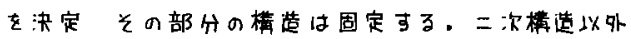
の部分の残基のめめを变数として 满造エネルギー の最小化を行う。棧造工札ギーを最小化する際に

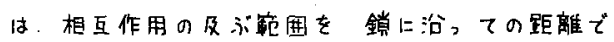
段階的に近いまのから遠いものへと度がっ川， て岛模型の考元を反映し相互作用も特界的にす 3 .

以上の手順で楛造エネルギーを最小代し蛋白筫 の折れたたみを行った。

2E 0915

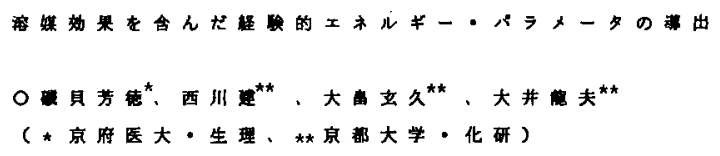

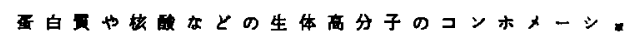

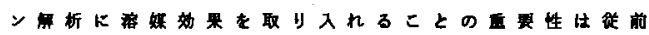
より十分四されていかが、これまてのコンホ夫

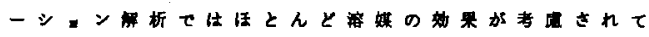

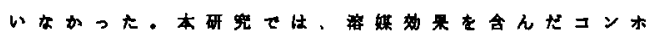

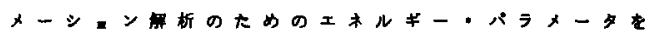

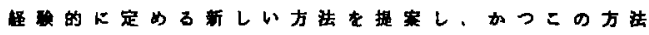

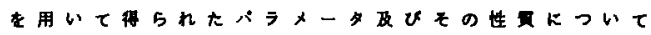
精告士口。

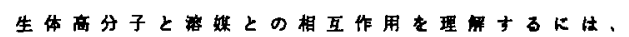

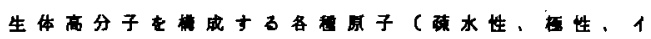

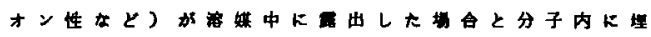
没した合の自由エれルキ一盖加分れ浩上い。本研

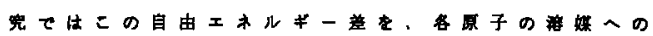

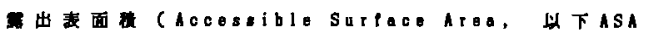

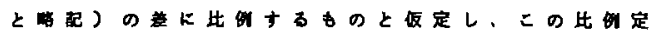

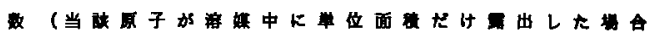

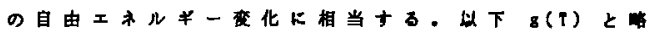

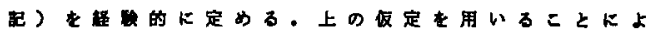

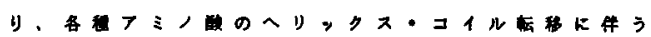

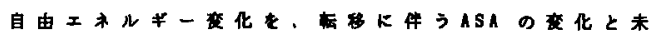

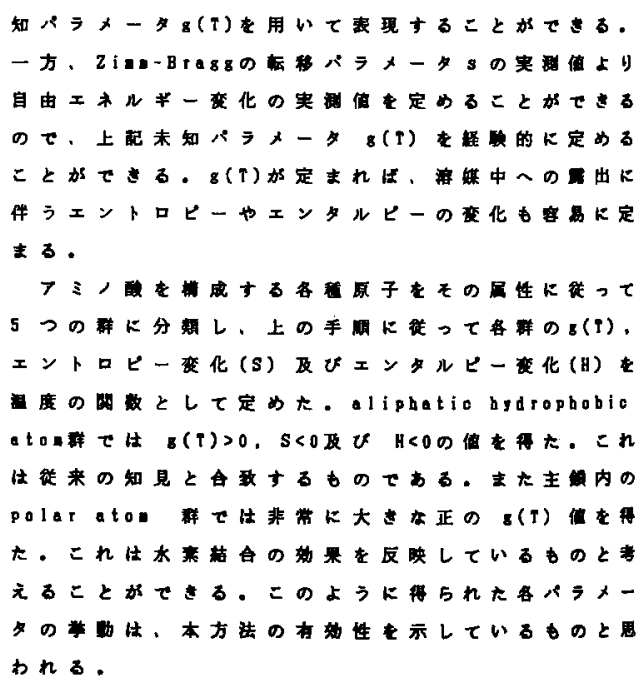




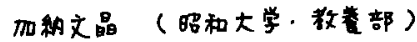

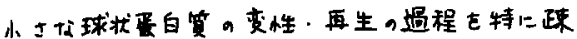

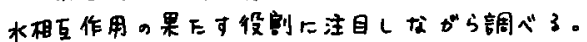

蛋白筧のモキルとして，右圆

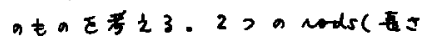

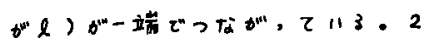

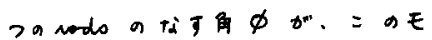

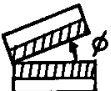

デルの唯ーの变数である。申がイさ

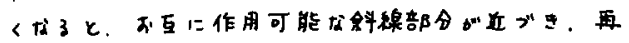

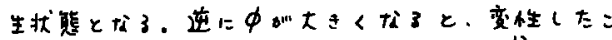

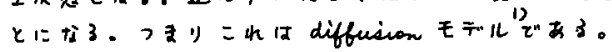

このモデルの規格化した相る作用の大きさを

$$
g(\phi)=-p(\phi)+q(\phi) \cdot f(T)
$$

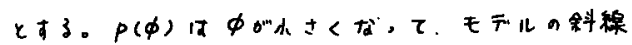

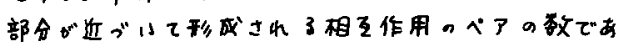
3. $q(\phi)$ 《. $\phi$ :

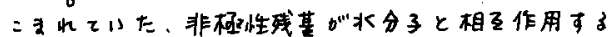

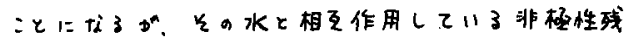
基の数である。二の第2项が疎水相互作用を表中す。

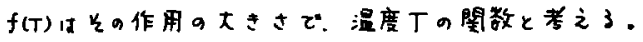

結果につルて楼演 で述ベる。

\section{E 0945}

\author{
Angiotensin II a畨造
}

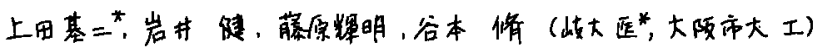

参照

\author{
1) M. Karplus \& $\theta$. L. Weaven, Hature 260 \\ (1976) $404-406$.
}

ペプチッドホルモンすどとれにど大きくないペプ チッドの楁液中の棈造は、羓一ではなく、いくつかの棈 造がある存在䬺率をもつて混ざリ合つていると考之

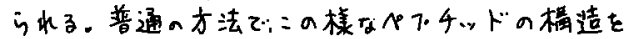

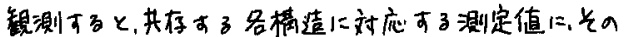

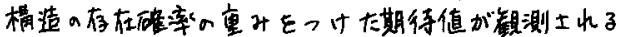

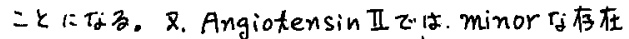
属率巨もつ棏造の方が生理活性が高いと推定さ水る 实駸事实がいくつかある。徒ってエネルギー計算か

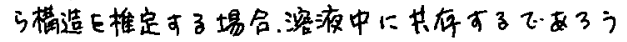

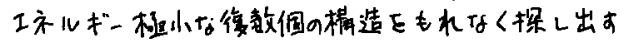

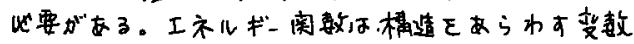
の寻变数阅数て，普通よく行わ水る句配法的どによる。

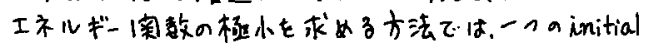
conformationから得られるエネルギー桠小を梢造は。 initial conformation からあまりはず水ていでい棈

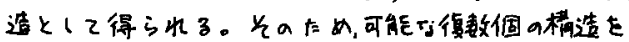

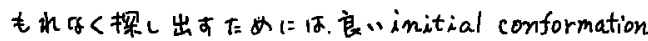
と连ぶことが优賏でる。

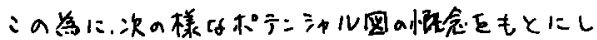
たスキームの自動化されたプロブラムを作った。

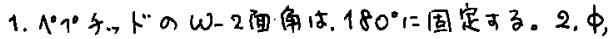

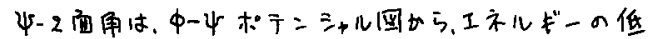

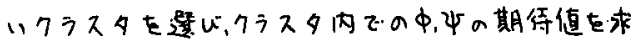

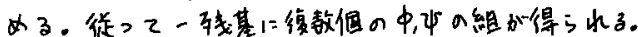

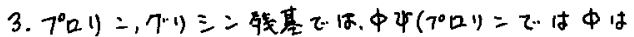

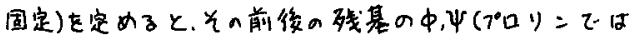
いも)に大さな影隻があることがかかったので、前後の

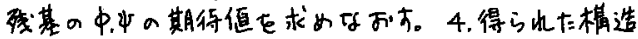

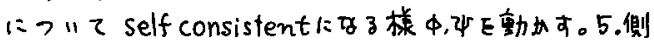

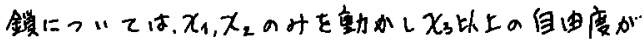

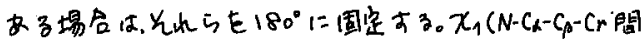
の二面解)は-60, $60^{\circ}, 180^{\circ} の 3$ 自由度とする. $x_{2}\left(C_{\alpha}-C_{\beta}-C_{\mu}-C_{\delta}\right.$ 間の二佃俑)は、 $C_{\beta} か ゙$ trigonal 崖素原子になる芳香 族アミ，酸.PRパラギン酸、アスパラギン、ヒスチジンで む $-90^{\circ}, 90^{\circ}$ ，他、アミ，酸では $-60^{\circ}, 60^{\circ}, 180^{\circ}$ の子に国定 क 3.

以上a 伭で. Angiotensin II (Asp. Ang. Val.Tyr.Ile.

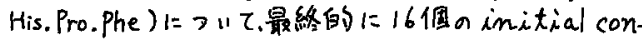

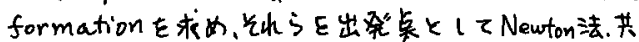
役句配法で最通化巨行“得ら水た棏造心対底可子CD， NMR E部算し、实测值と一致の良”結果E得卡。 
消化管ぺプヶドホルモンでおるがストンおなじ コレシストキニン ( c c K 33$)$ は 端部に共通の

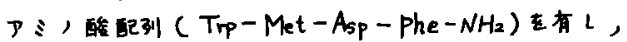

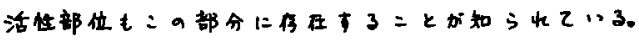

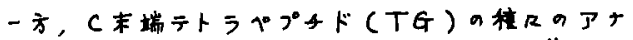

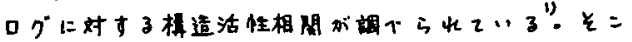
で，找及はまず，丁Gの活性请コンフォメーション

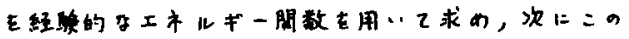

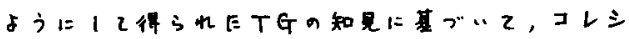
ストキニンのC来㙐フラグンントであるCく

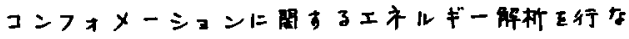
$\rightarrow$.

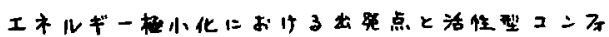

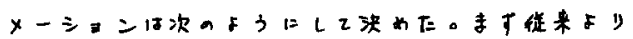

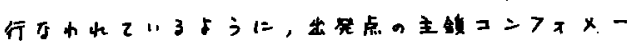

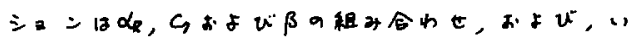

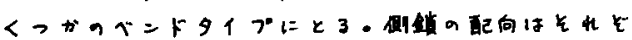

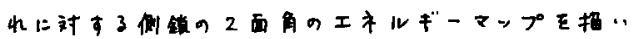

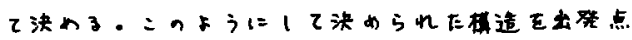
として丁Gの好小れルギーコンフォメーションC

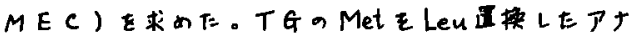

口グは活性が保持さ邨ことが知うれているので， TGと:のアナロゔに共通的低エネル゙ーコンフォ

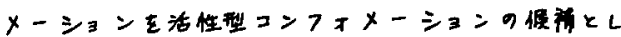

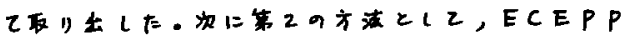

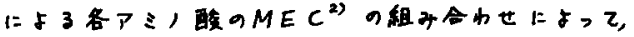

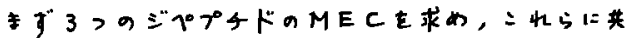
通する样造から2>のトリベタドのMEC，士う に月模ににてTGのMECE求め3.:の剒合にも，

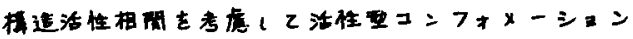
士浃める。

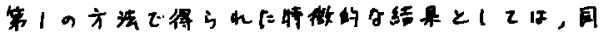
㮛度の低“エネルギーをもつコンフォマーが数存 在することがかった。ニのニとい，丁Gは水涑

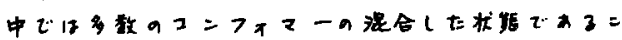

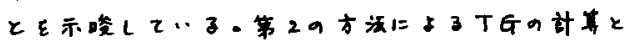

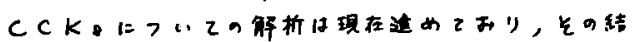

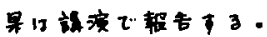

1) Morley, J.S., (1968), Proc.Roy. Soc. B., 170, 97 - III

2) Vásquez, M., Némethy, G., and Scheraga, H. A., Macromolecules, $(1983), 16,1043-1049$

2 E 1015

\section{インスリンの栋的植廷}

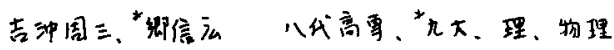

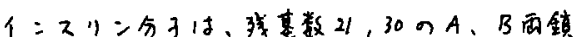

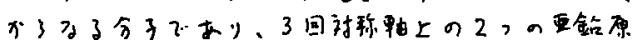

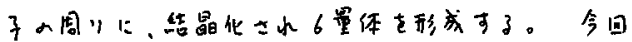
、成々は6量体中のにつの分子であ了可子正注目

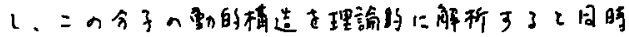

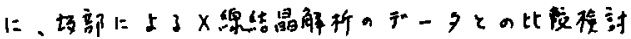
を行みう。

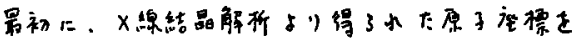

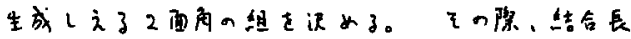

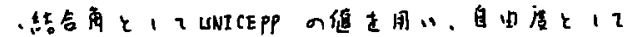

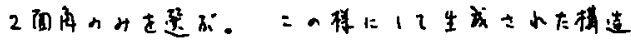

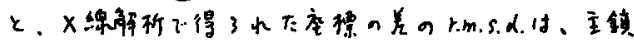

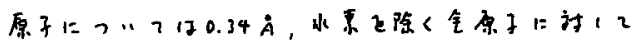

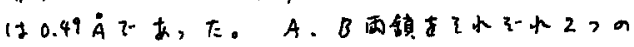

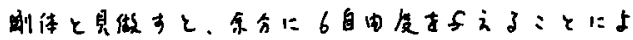

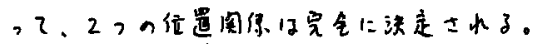

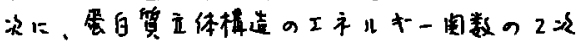

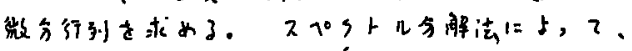

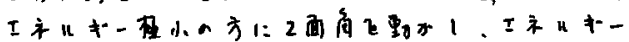

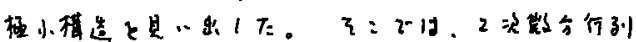

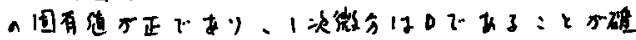

涩され下。

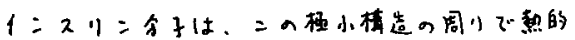

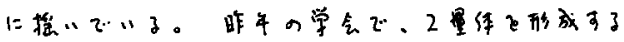

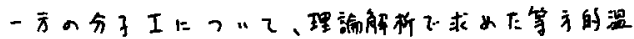

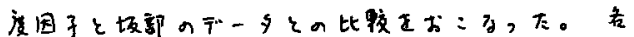

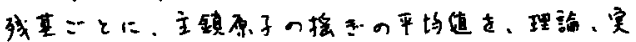

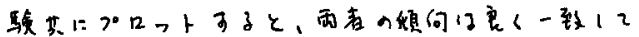

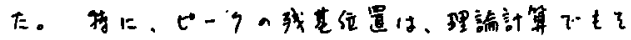

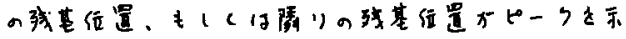

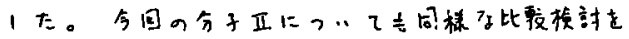
行みう。

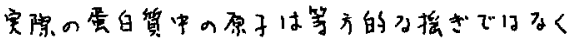

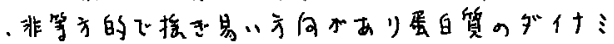

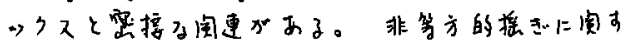

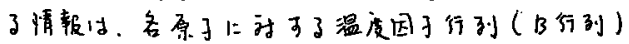
に上，乙求め了小子。二のB行列小国有值の平方 根は、各愿子の摇ぎ棈风体の主看の長さを5之了。

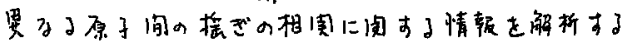

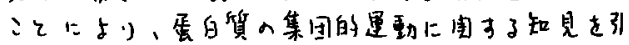
出出。 


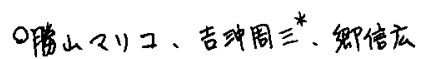

分子の安定模造は、X绎解析による座䍒データを

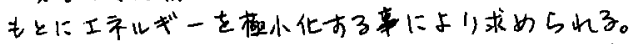
ンの方去を用いる事によって亿ミ1酸配列のうち幾

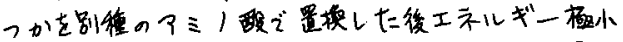
化を行なえは，是换後の\}三人酸配列をもった蛋白

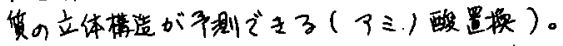

bovine pancreatic tripsin inhibitor (BPTI)に15泟りのア三1酸置换(一残基置 模）を行子った六、以下のZつの結果が得られた。

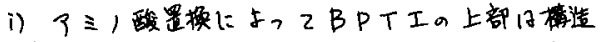
変化を起こしメ可く下部は起ニレにくい。(因 参照）

ii)低辰動モードは、代学棈造に与之られたア三

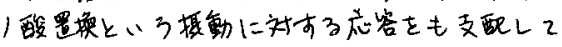
いる.

さらに二の手法をアミ1酸か数调是なる相同蛋白

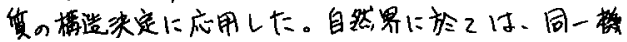

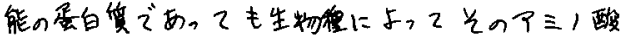

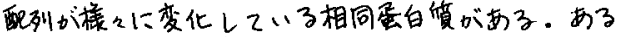

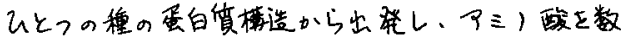
㑑是换してエネルジー枢小化を行なう事により、个
（九大・理、八代高尃*）

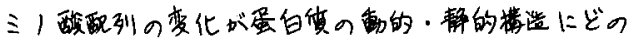

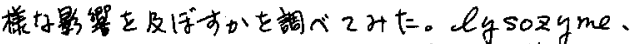
ovomucoid. BPTIの3種の委白鿓につい

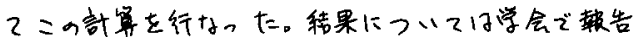
おる。
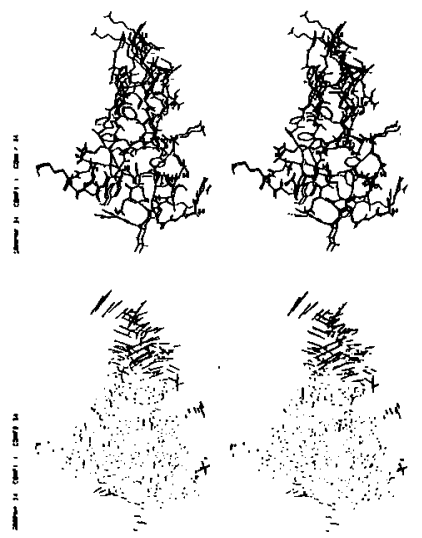

2E 1045

球状蛋白筫における变性・再生通程の統計热力学的アプローチ

“安部晴男，鄉信広”西日本工大・教羔，九大.理”

球犹蛋白質の变性・再生過程民，统計热力学的立 場から理解し，解明する为に次の手暊を考察する。 [i] “蛋白望分子”+“溶媒”からうる系での，す

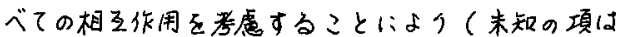
パラメターとする)，溶湤中での蛋白筫の变性状 態と，生状態との ギブスの自由エネルギーの差， $\Delta G は ， 2$ 状態転移を仮定すると，温度の関数と iて次式で表瑅できる。

$$
\Delta G(T)=-R T \ln \left(Z_{\boxplus} / Z_{N}\right)
$$

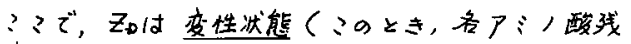
基は独立にふるすい，他のすべての残基の影很は熙 視でアるものとする)での分配剧数であり， $Z_{N}$ は，

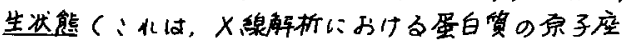
骠から出笔して，我々の用いる立体楎造工ネルギー 関数最小化して求めらイるコンフォメーションと

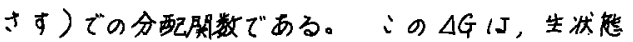
の猎白筫の安定性を評洒できる量的尺度であるとみ ぬされる。理論に表われるパラメタ一は，变性曲

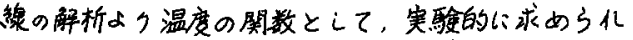
ている $\Delta G$ K，光の内容 $\Delta H, \Delta S$ ”決定する。 [ii] 球状等白質の变性・再生遏程は，可逆的であう，
非常に坫同性が高い门次相転移的瑅象である。?9 己とは，転移温度 $\left(T_{d}\right)$ では，蛋白筫分子は变性状 態か，生状態かのど5らかの状態にある碓率が大き い:とを意味する。それ敌，蛋白筫の折小ただみ の道萠飞推定する为には，反应座標として，内部秩 序度をとる必要がある。(i门で求めた $\Delta G\left(T_{\alpha}\right)$ を 用いて，内部秩康度( ?:では，折化にだの中周 投階にみいて，生粗造と局所的に同じ㭗造をとって いるアミノ酸残基の数，nをとるうの開数として，

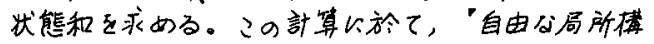
造模”（局所構造間，及心゙局所棈造とランダム。 コイル状態にある七ブメントとの相互作用は盘视し ている)を用いる。:可状態和からある内部税序 度(n)を毛つ、すべてのコンフォメーションをサ ンプルし(トラップする考え)，各アミ，酸残基が， 局所槽造を形成している辟率を求めて，平衡での蛋 白貨分子の折れだは引の道能を推定する。

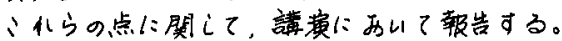
[文献]

1) Privalov, PL. (1979). Adu. Protein (hem, 33 2) $G \bar{o}, N . \&$ Abe, H. (1981). Biopolymers, 20, 991 1011. 


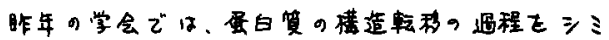

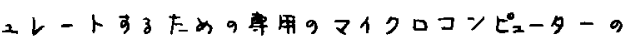

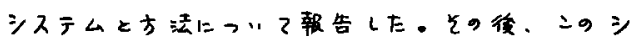

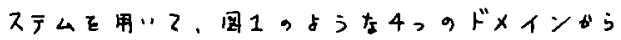

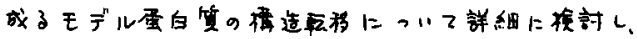

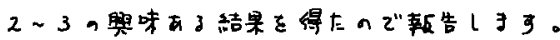

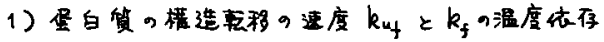

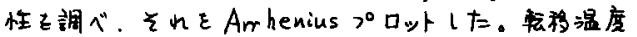

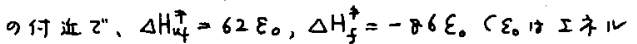
ギ一单位)とを，た。N状惩、U状態，平均エネル

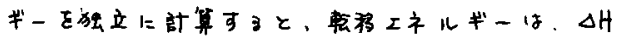

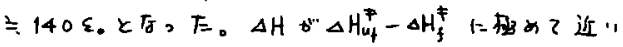

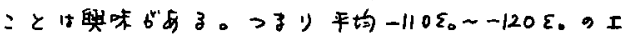

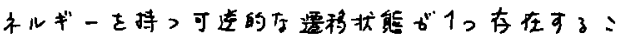
とを意啸している。

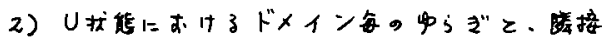

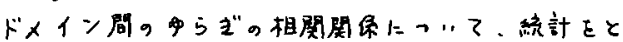
つ乙調べた。(㱟工)。绦接ドメインい独立上再生

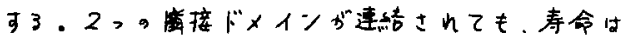
2 借程度しが昨じない。

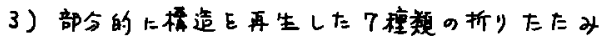

中成体。完全に全棈造を形成了る神率を誈べた。它

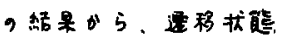

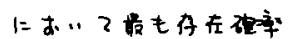
の高川央型的去模造を 推定1た。专た。乥” 樓道己通通して所》三 E天山了央整的折》た たタ往路们何にーーナ

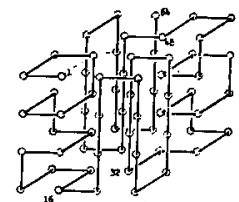

(图 1)

トぐら."

9 碃率?"

通遇工凡

$361=2$

いマも萧

敦する。 (表 I)

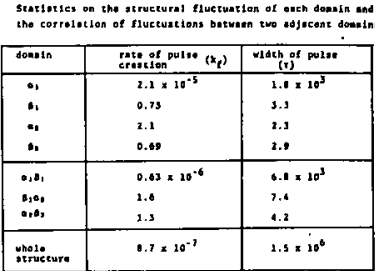

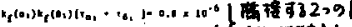

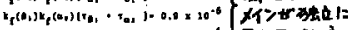

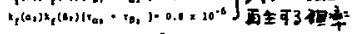

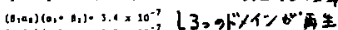

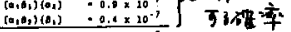

2E 1115

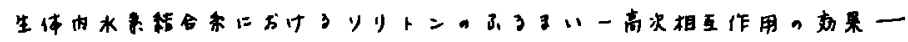

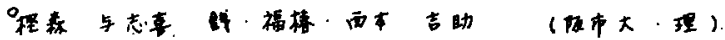

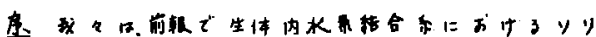

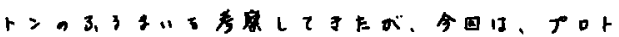

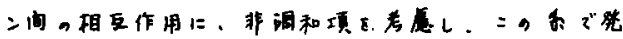

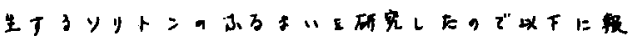
告 3 .

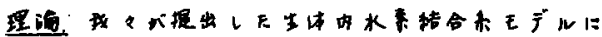

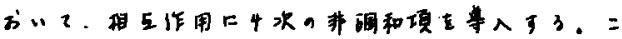

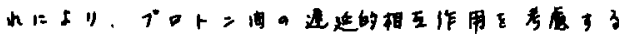

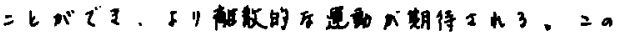
63. . Hamiltonian 17

$H=\sum_{i}^{n} 1 / 2 \cdot m \dot{r}_{2}^{2}+\sum_{i}^{H}\left(-1 / 2 \cdot r_{i}^{2}+c / 4 \cdot r_{i}^{4}\right)$

IF。显策方程式口。 $+\sum_{i}^{n}\left[\left(D_{2}\right)\left(r_{i+1}-r_{i}\right)^{2}+\left(x_{4}\right)\left(r_{i+1}-r_{i}\right)^{*}\right]$ (1)

$$
m \ddot{r}_{i}=\left(A r_{i}-\left(r_{i}^{3}\right)+D\left(r_{i+1}-2 r_{i}+r_{i-1}\right)\right.
$$

$$
+x\left\{\left(r_{i+1}-r_{i}\right)^{3}-\left(r_{i}-r_{i-1}\right)^{3}\right\}
$$

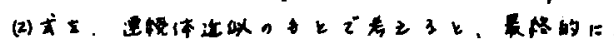

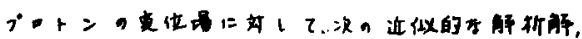

$\tan ^{-1}(\sinh \zeta)+\left(a_{2} / 4 \sqrt{a_{1} V_{0}}\right) \sin \hbar \zeta= \pm\left(U_{0} / a_{2}\right)^{k / \frac{1}{r}}(x-\Delta t)$ (3)

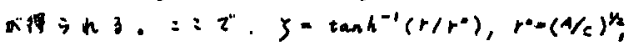
$a_{1}=3 x_{1} \ell^{t} / 4, a_{2}=0 \ell^{2} / 2\left(1-v^{4} / c_{0}^{2}\right), u-A^{2} / 4 c, t E$. Hamiltmian (1) $<$ H (4)

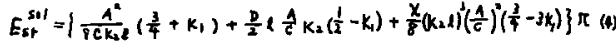

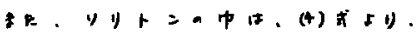

$$
\Delta L_{s+1} \sim\left(\frac{3}{4 \mu}\right)^{1 / 4} 2\left(2 r^{\circ}\right)\left(3 \cdot 28 \sqrt[4]{x}+\frac{1.28 D}{4 \sqrt{3} \sqrt{v_{0}}} \frac{1}{\sqrt[3]{x}}\right)
$$

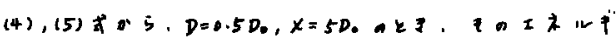

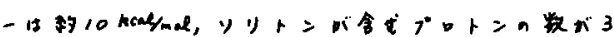

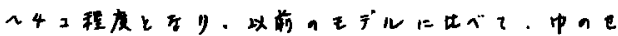

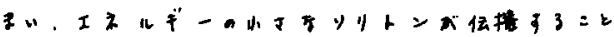

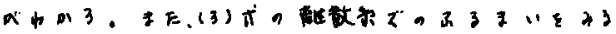

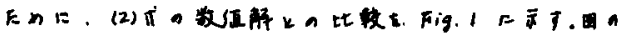

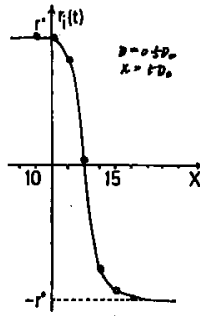

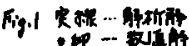

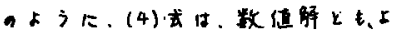

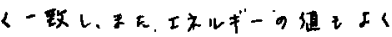

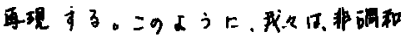

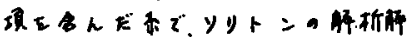

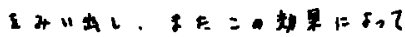
ソリトンா、收前のもデルに比て?

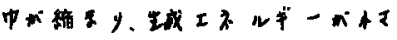

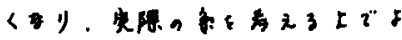

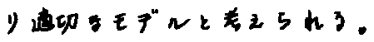




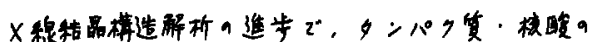

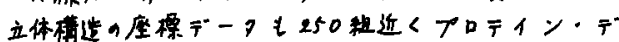

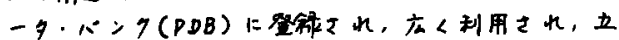
体椣造

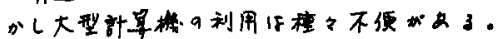

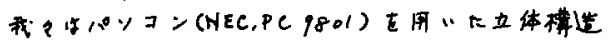

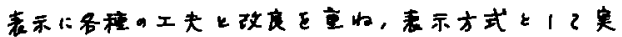

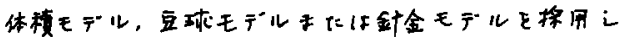

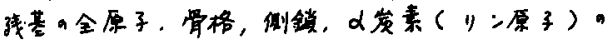

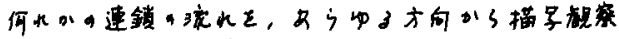

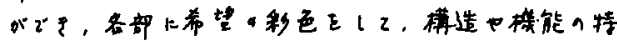

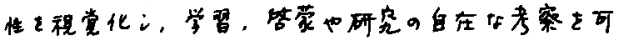

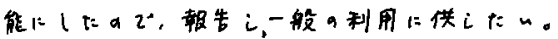

\section{㑑影要用フロンピ一デスクの整作}

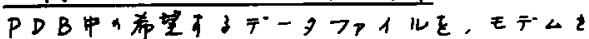

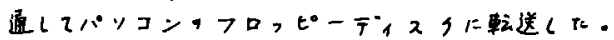

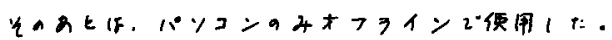

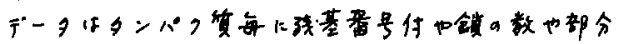

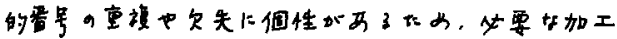

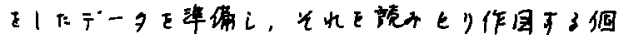

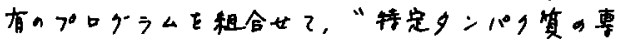

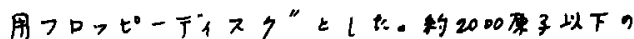

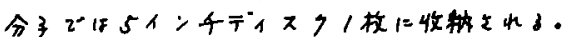
立体碃违表示プログラム、楼能湉用

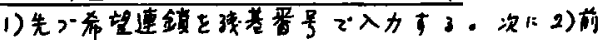

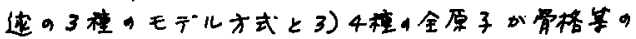

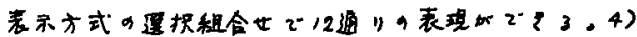

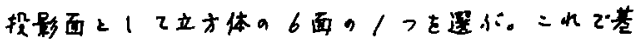

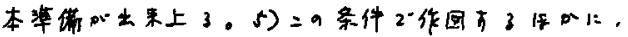

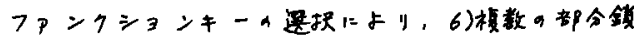

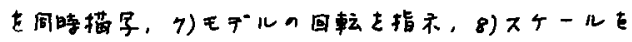

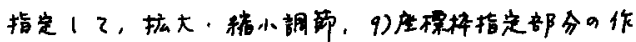

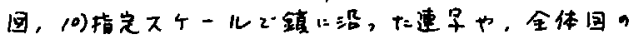

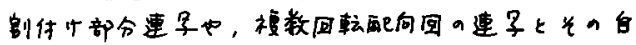

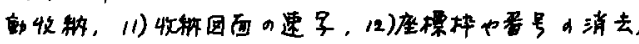

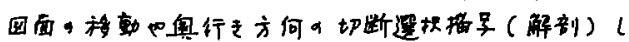

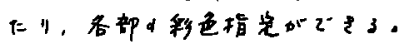

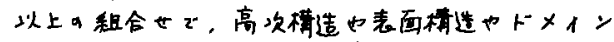

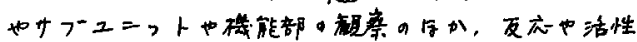

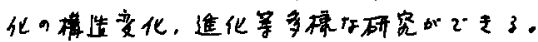

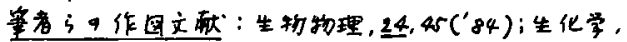
s6,No.5, 口答 ('P4); Nacl.Acid Res, 12,801( 84).

2E 1145

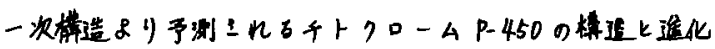

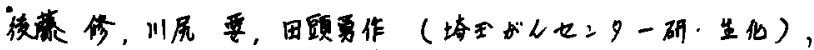

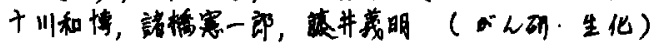

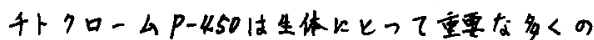

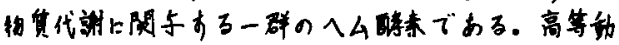

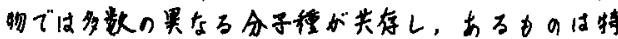

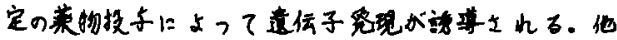

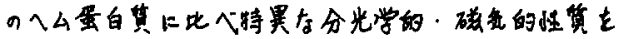

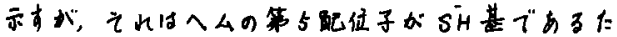

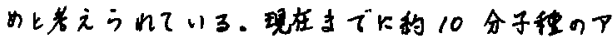

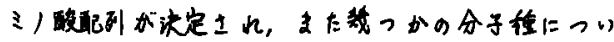

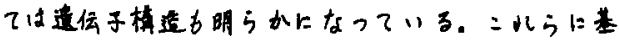

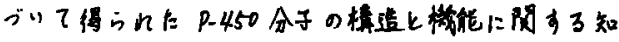

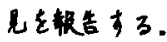

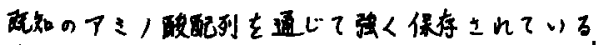

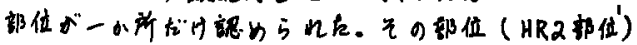

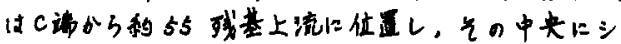
ステイン我基を含け。:のシステインのSH基がへ

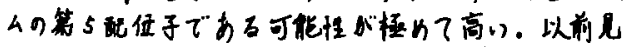
出士れ的もう一のの保存部位（HRI部住）は他の分

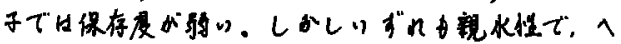

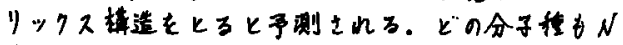

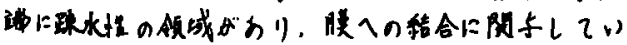
ろ九のと思版る.
因1はヤミ/映配列口基 ガく貄々の分子程の間の系

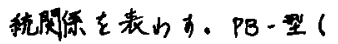
$P-450 b, e, L M 2) k M C-$ 聖 ( $P-450 C, d, M C 3)$ の分岐注唃 柇勃物の出现以前に超二り， 险:トコントりアでステ

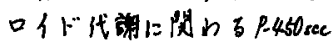
は更口以前红分化した $=$ と

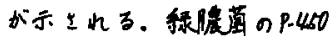
1舟子伝连系の数似性から

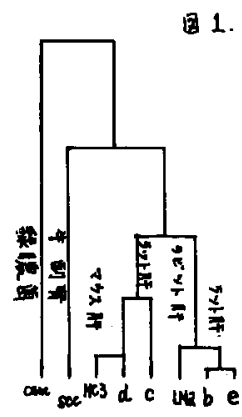

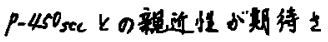

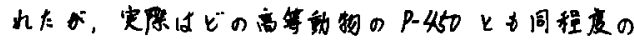

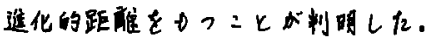

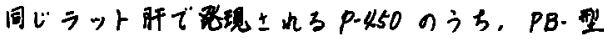

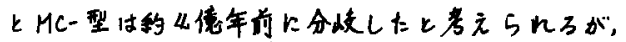

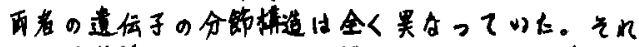

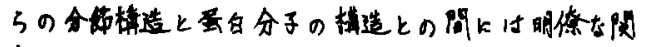

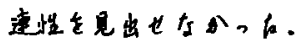

1)

0. O.th et al. (1983) J. Biochan. 93, 807-817. 
動的党光消光のよう方搪散律速反应心は本来境界条， 件の影響を非常に强く受けち。したがっ2、萤兆消

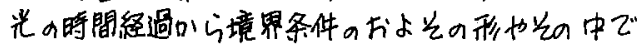
の杭散速度を評価できるけずで历る。本研究を合ま 一速a研究ては例之ば輸送タンパクの千ーネル等の 限らんた空間の中て起:る萤光消光がに゙のような時 間経過をたどらい。また。光れを利用し乙实際に千

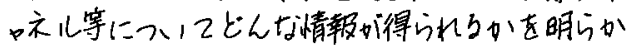
に才る。本研究はとのうちの理唃的边部分公ある。

[モデル]

限SUt空間と(1,2光 色々た形があるか゚、国1(a) で示されるようたミセ儿内 の消治に対広才学場合や(b) におけるチャ礼内。色素 の消洸に対応寸ら埸合、い ボれも適当枋条件下で( )に 示LE一次元的拉散モデル と等価に方子。气二で因1 (C) 境界条件下での松散律 速反㐫の問題与解く。
田1.

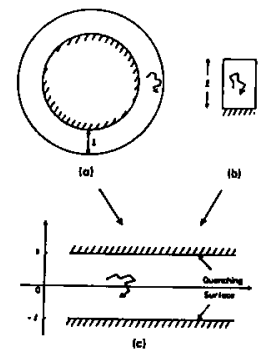

[結果]

計算の結果我てが考察しているよう十境界条件下

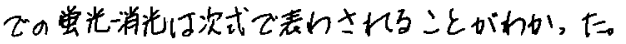

$$
\begin{aligned}
& q(t)=I(t) / I_{0}(t)=q_{\infty}+\left(1-q_{\infty}\right) Q(t) \\
& \left.1-q_{\infty}=m C_{0} / C_{D}-C_{m c}\right) \\
& Q(t)=(8 / \pi)^{2} \sum_{\pi}(2 m+1)^{-2} .
\end{aligned}
$$$$
\exp \left[-12 /\left\{\pi^{2}(2 m+1)^{2}\right\}\left(t / \tau_{\theta}\right)\right]
$$

ただし、 $\tau_{Q}=\ell^{2} / 30 、$ mはミセルa場合、凝集分

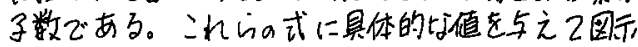
したもの因2と四了である。

国2.

国3.
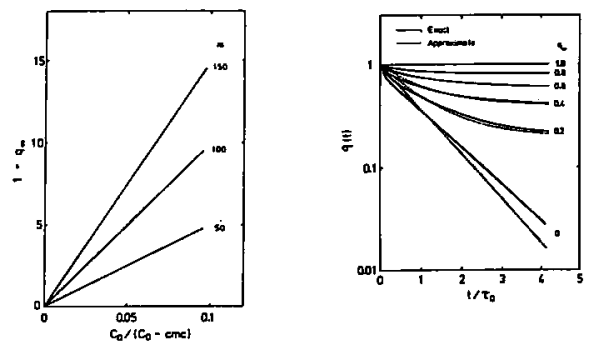

2 E 1345

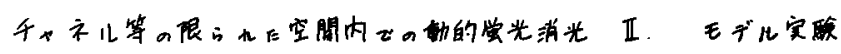

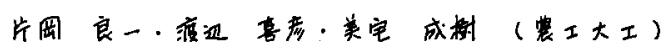

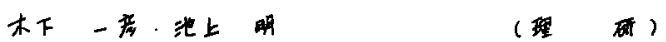

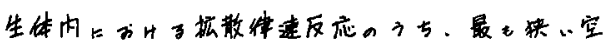

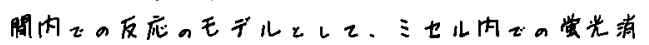

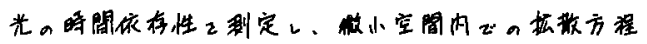

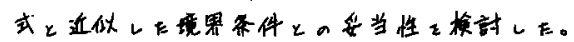

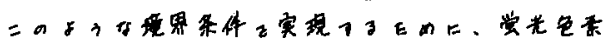

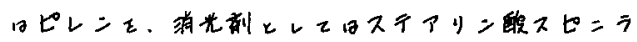

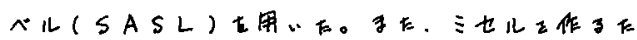

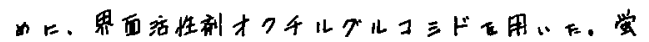

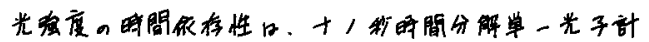

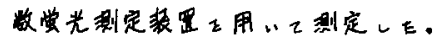

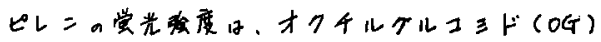

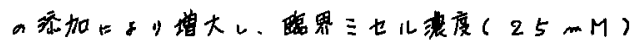

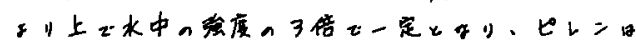

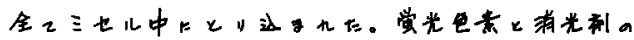

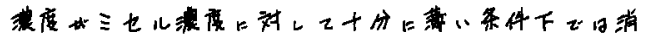

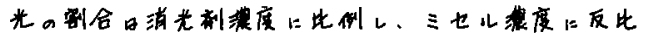

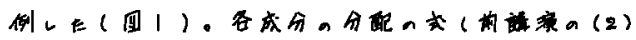

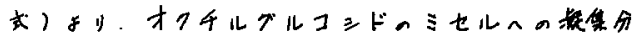

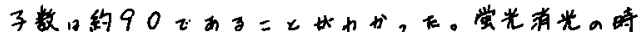

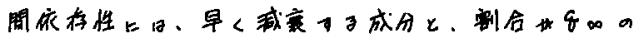

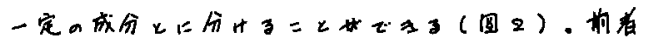

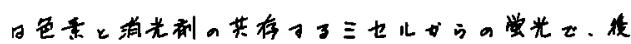

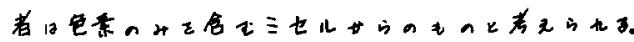

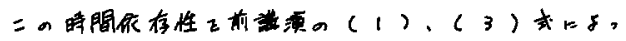

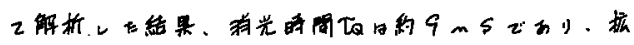

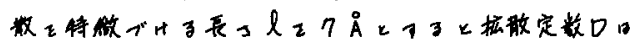

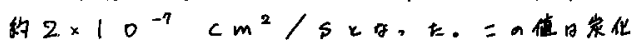

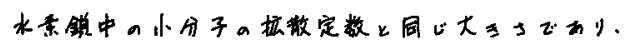

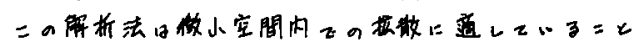
か示㖡ニれた。
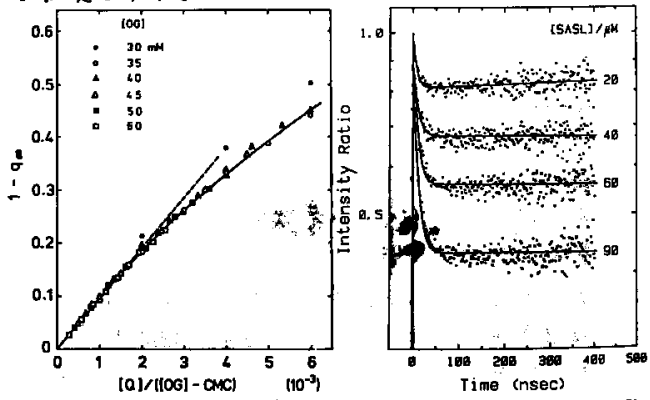

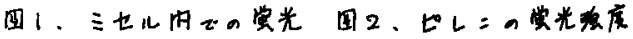

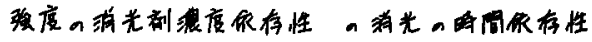




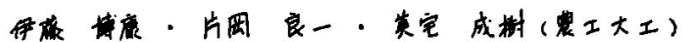

木下一者。地上明(理化学研究并)

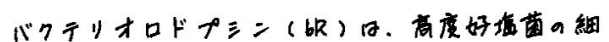

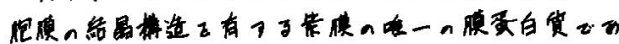

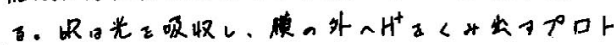

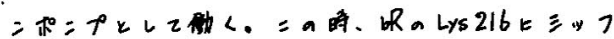

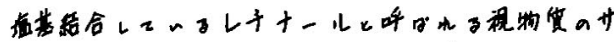

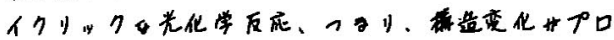

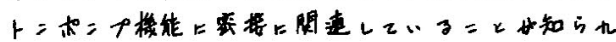

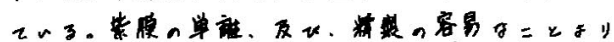

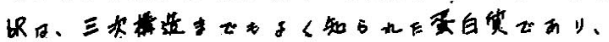

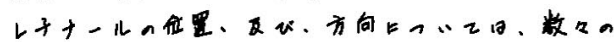

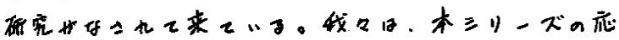

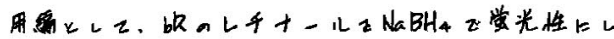

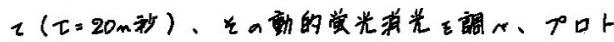
ンaチャネルと みるぬわ口空間 上月…2是知晃 E。四一个

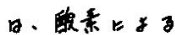
尝光消光实路。 的籼定口结果 \& Stern-Volmer

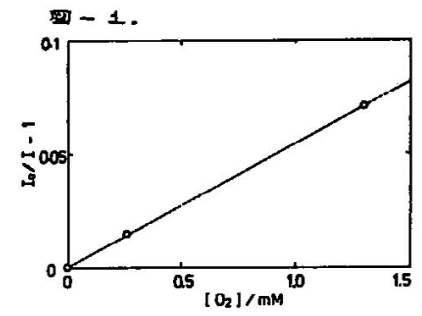

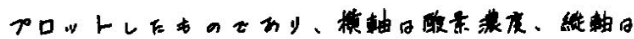

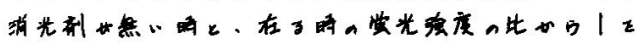

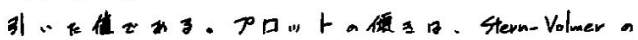

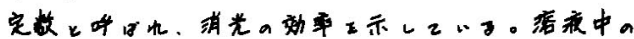

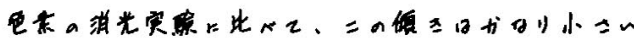

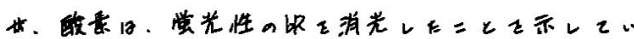

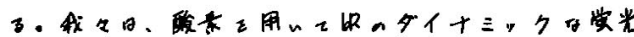

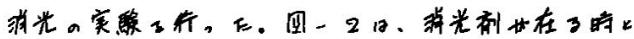

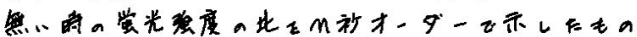

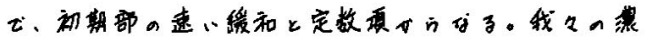

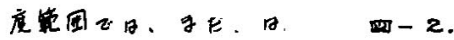

(3) $x$ dynamic if 捎光

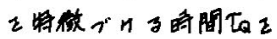

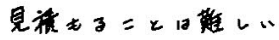

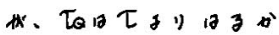

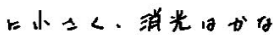
少短、的闌七起, 乙一

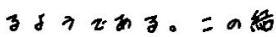

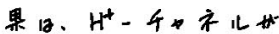

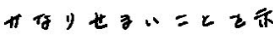
破七ている。

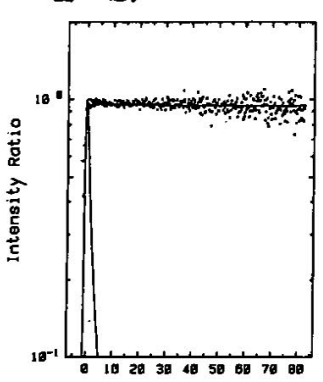

$2 E 1415$

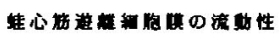

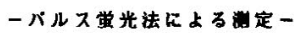

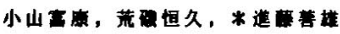

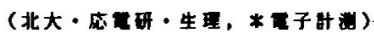

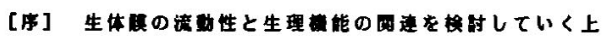

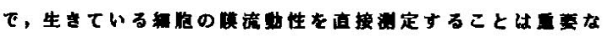

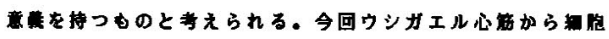

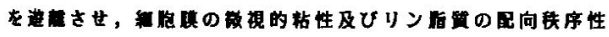

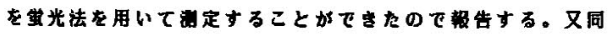
ヒくウシガエルの赤血践についての同样の划定を行なった

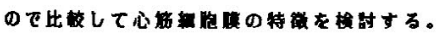

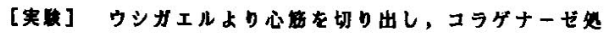

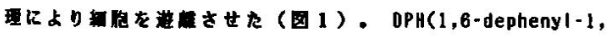

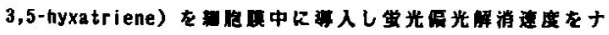

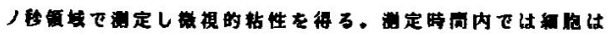

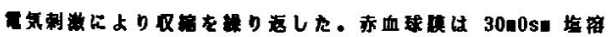

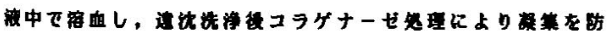
る周椄の垱定を行なった。

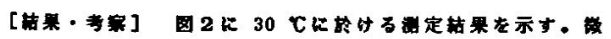

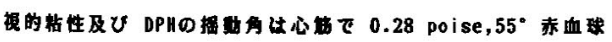

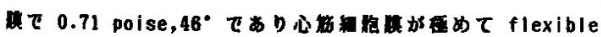

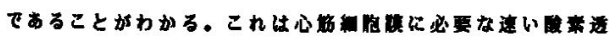

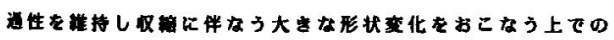
特就てあると考えらんる。

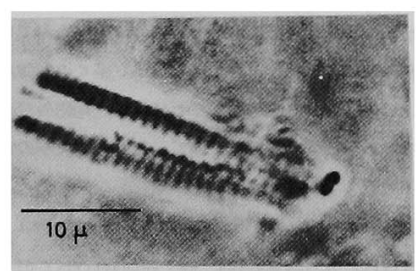

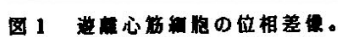

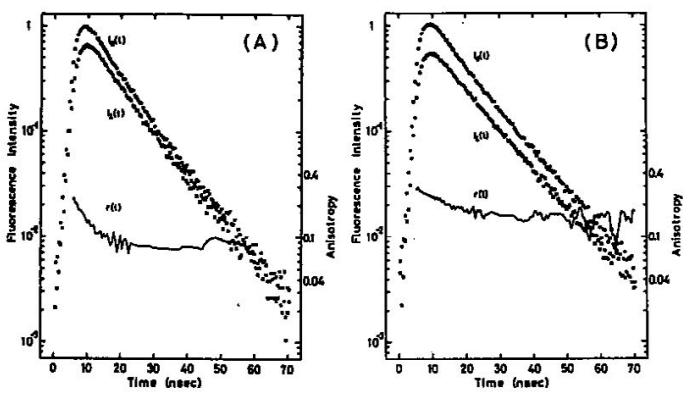

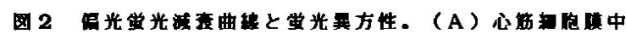

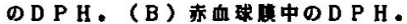




\section{○阪本一央平檌冷（東大·教養·化学）}

一般に苦体発現には受容膜中の脂算に閧保が深い ことが、膜圧や膜零位の測定なビから示惨されてい る。しかし、膜の流動性を取报、た例は少ない。

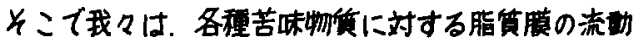
性变化少らびに相転移昷度变化をESRを用い，ス

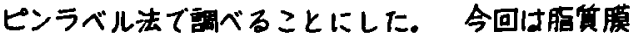
としてDPPCを用いた系における結果を辄告する。

実眵には 5-DOXYL-stearic acid をスピンラベル剂 として用い、これてラベルされたDPPC庵を各程苦

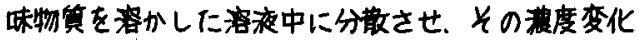
ならでに温度棸化をESRで測定した。

結果には膜流㲜性の指標としてオーダーパラメー ターを用い、これを用いて各種苦味物筫ごとに相踣 移温度変化区調ベた。四1.に长のー例を示す。 この图からDPPCの相移温がニコチンにより低 温度㑡にシフトしていることがわかる。きた。 オ ーダーパラメーターを漠度に対してプロットした等。

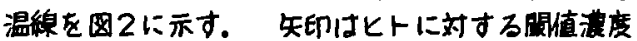
を示しているが，长れ为れ閔值付近の浱度でDPPC 膜の流到性が大きく变化する結果汃得られた。 これらの結果は、苦味物筫がある源度（閶值）て
脂筫䐵の流勤性に大きく变化を与え，2の变化が苦 㕲発現に閶与していることを示唤するものてある。

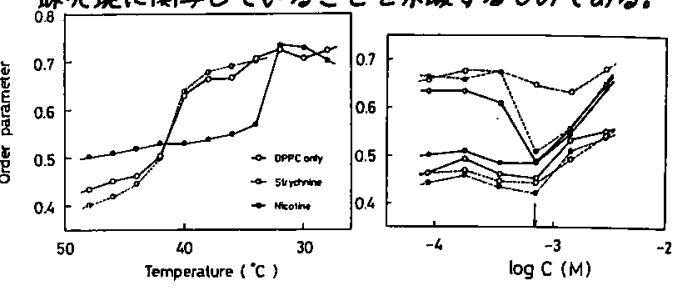

因1相输移温度变化国2(b) カフェイン

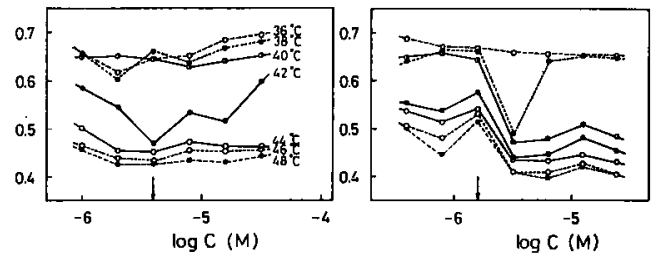

四2(a) ピクリン政

2E 1.445

組粰インピーダンス测定 I

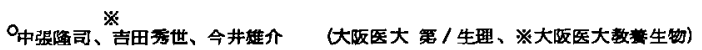

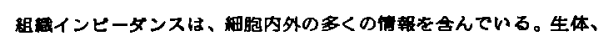

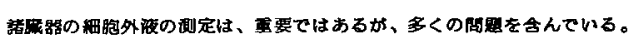

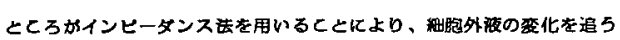

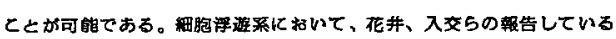
(/) 式势用W

$$
\mathbf{K} / \mathbf{k} \mathbf{n}=(1-\Phi)^{3 / 2}
$$

$K$ : conductivity of suspension $K$ II : conductivity of mediuI Q: volume fraction

この理論を用いて、インピーダンスアナライザーを使用し、 $5 \mathrm{~Hz}-13 \mathrm{~Hz}$

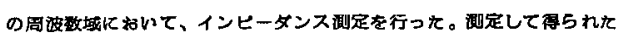
データは、 cole-cole plot (resistance-reactance) を行った。 また、湿られたデータを円弧て、fittingを行い、それそれ、高䦤、

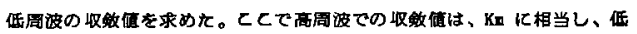

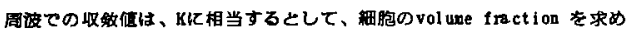
ז。

また、赤血球を用いた細胞祥遊柔でのインどーダンスを测定して。サボ

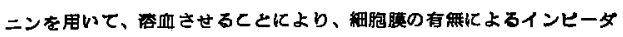

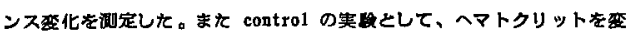

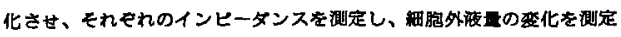
した。

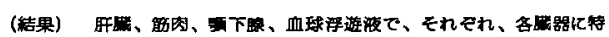
有のcole- cole plot のパターンを示した。いずれの堨合も円刷をもっ て fitting 加可能でおり、各紫器によりモのphase angle は奥っていた。

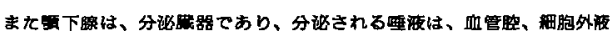

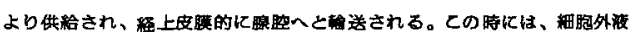
は大きく登化するととが䐓待される。その時のインピーダンス要化を测定

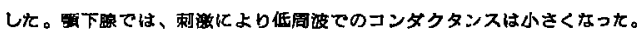

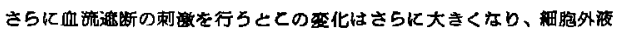

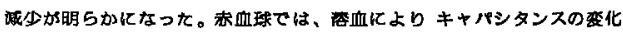

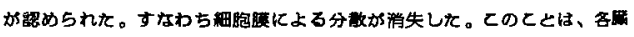

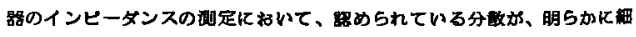

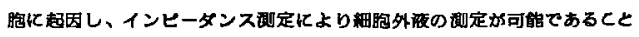
を示すものと考える。 


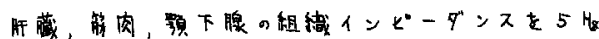
〜13MH筆田で测定したところ、いくつかの特牧

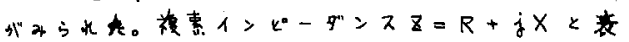

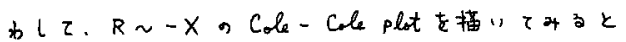

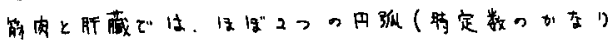

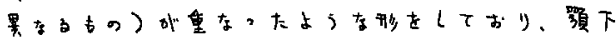
腺の堨合士非常につふれた用弧の形をしている。 长を定量的に表方すために，次式

$$
Z=R_{H}+\frac{R_{1}}{1+\left(j \omega \tau_{1}\right)^{\beta_{1}}}+\frac{R_{1}}{1+\left(j \omega \tau_{2}\right)^{\beta_{2}}}
$$

で curve fitting t行つてみた。山は角周级敬で $\omega=2 \pi f$

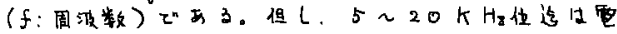

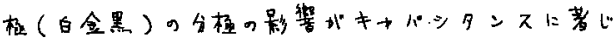

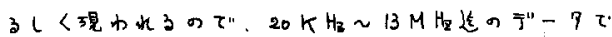

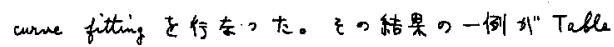

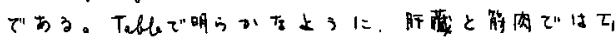

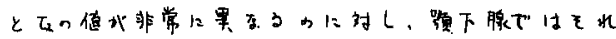

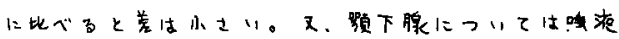

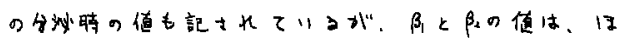

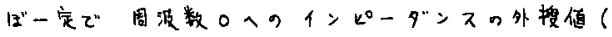
$R_{H}+R_{1}+R_{2}$ ，值)が分泌时に增元こ“る。血流遮断

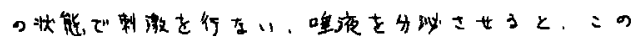

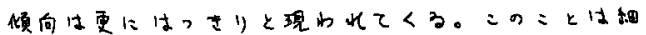

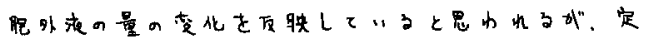

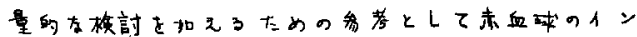
ピーダンスをへマト7リット值を芭又变えて测定し

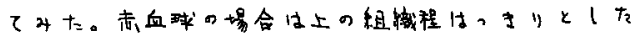

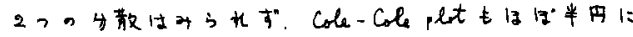
近“ものであったーマへマトクリ川卜值と等电率の

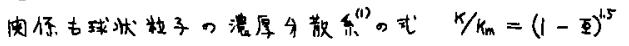
にはは近いものであった。

\begin{tabular}{|c|c|c|c|c|c|c|}
\hline 生蜮 & $\tau_{1}\left(\mu_{\mu \mathrm{\mu c}}\right)$ & $\beta_{1}$ & $R_{1}(t-4)$ & $\tau_{2}(\mu \mathrm{sec})$ & $\beta_{2}$ & $R_{2}(t-4)$ \\
\hline 时藏 & 6.8 & 0.71 & 860 & 0.5 & 0.9 & 260 \\
\hline 符肉 & 3.6 & 0.76 & 670 & 0.12 & 0.97 & 120 \\
\hline 䫑下腺 & 1.7 & 0.72 & 144 & 0.23 & 0.87 & 210 \\
\hline (方归㭙) & 2.4 & 0.17 & 200 & 0.28 & 0.85 & 270 \\
\hline 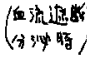 & 3.8 & 0.71 & 290 & 0.5 & 0.82 & 320 \\
\hline
\end{tabular}

文献 1) T. HANAI, "Emulsion Science" P. Sherman, Ed。 Academic Press, London-New York, 1968
2E 1515

\author{
腎上皮由来培㤗细胞( MDCK)
}

高知医大・生理

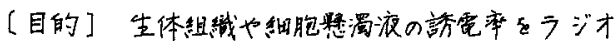

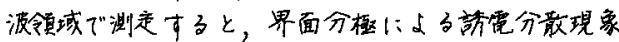

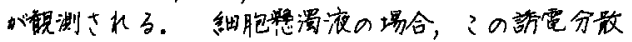
は基本的卜款付球モデルで领明で、る。首して， :のモデルに基づいて，多くの细胞で限界暚や細胞

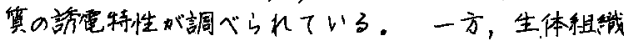
では，细胞同志が複雑に結合しているだ，ほとん

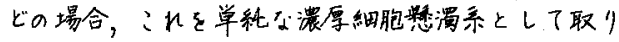
极う:とには要理がある。(たがって，組䋐の訪

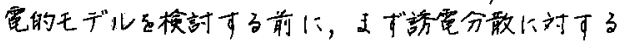

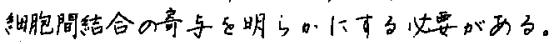

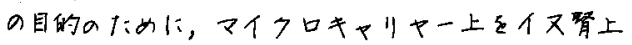

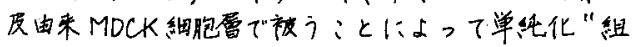

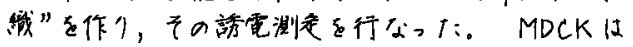
细胞間にタイト结合を形成才る:とが知うれている。 [方法] マイフロキャリマー, Cytodex 3 (平均 道径 $175 \mu \mathrm{m}$ ，Pharmacia）上l:付着：世 $I$ : MDCK细

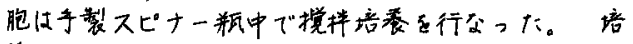
羡液隹は, MEM-Dulbecco $(90 \%)$, FCS $(10 \%), 10 \mathrm{mM}$

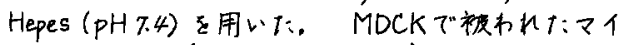

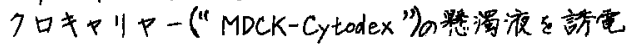

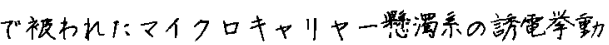

浅胃耕司，入交昭参

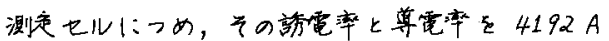

LF Impedance Analyzer so

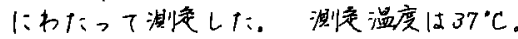

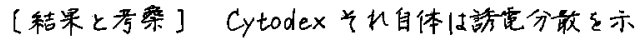

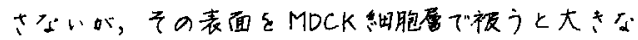

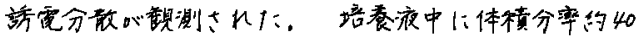
$\%$ で榡渴（斤埸含，分散の缓和強度 $\Delta \varepsilon=6 \sim 7 \times 10^{4}$ ， 缓和周波数 $f_{c}=1 \sim 3 \times 10^{2} \mathrm{KHz}$ であった：ａ淴 合，细胞のみの体積分率はだげか10\%である?と を考えると，学ふる细胞分散系では、のようょ大き

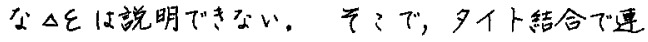

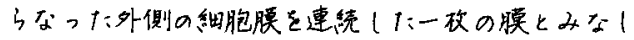
て，“MDCK-Cytodex”ト対してーつの款で国まれた

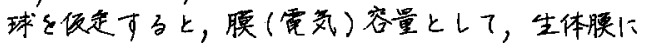

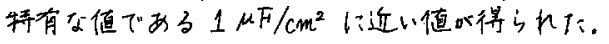
ミの:とは，矛一近似として，タイトに結合した細 胞曷で被われたマイフロキャリヤーは新管的には1 との大きな䋵のようによるまう:ととホしている。 


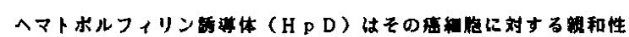

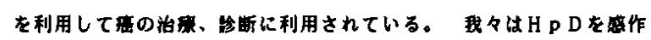
させたりンバ球に菜外光を照时して生したラティカル贯をESRによ

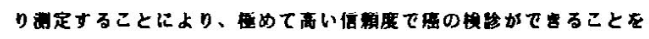

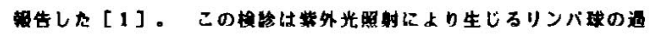

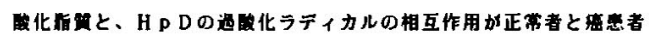

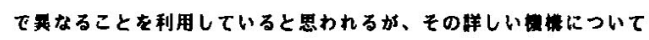
はまだ明かになっていない。今回はH pDの党光スベクトル、虫光

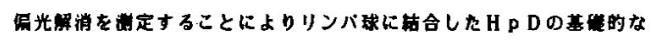
性䨢を明ベ、次の事が明らかになった。

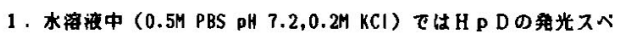

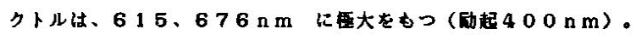
2. リンバ球に感作したH pDの発光スペクトルは $615 \mathrm{~nm}$ 、 $634 、 676 \mathrm{nmk}$ 虔大持っ（图 1)。

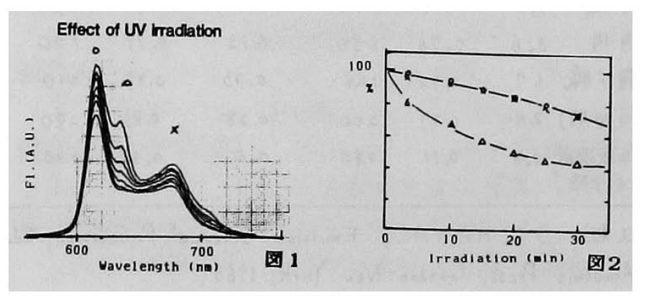

3.634nmのビークか他のヒー クょり歖外光に対して消光され易い。 (图1、2))

4. 定莹光的书 $(400 \mathrm{~nm}) k$ る615、634、676 n mの䖝光 基方性 (anisotropy) はそれそれ、 $0.014,0.060,0.026$ てある。

5、リンバ球に感作したH pDの重 光夷命红 $16.0 \mathrm{~ns}(60 \%)$. 4. $0 \mathrm{~ns}(40 \%)$, Anisotropy

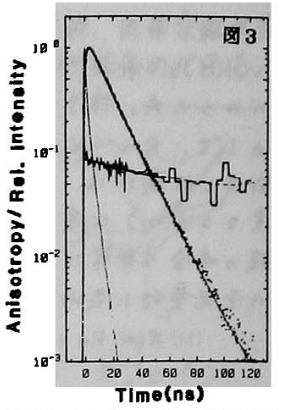

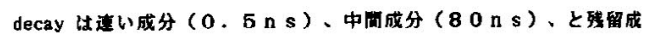
分 $(r=0.05)$ となっている(图了)。

上記1ー4より、634nm のビークはリンバ球に结合したもの

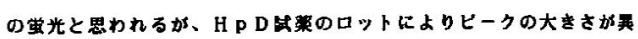
なるため、H p Dの有奻成分（HPL Cにより7成分に分国されてい

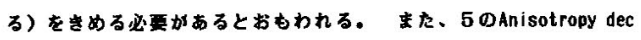

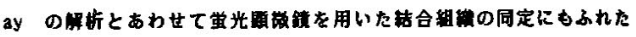

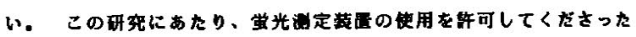
理研生物物理の池上主任、木下氏に感㽗致しむす。

[1] 虚の床 $30(1984) \quad 39-45$

2E 1600

発癌遺伀子産物による膜蛋白質にでインシトールリン脂筫のリン酸化

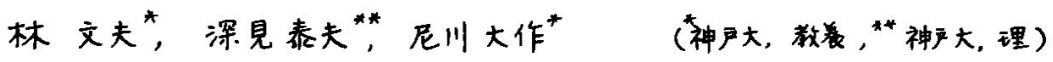

ラウス内腫ウイルスの発䖈遗伝子( S r c ) の遗 伝子産物 Pp $60^{\text {src }}$ は.タンパフ筫中のナロシン牫基

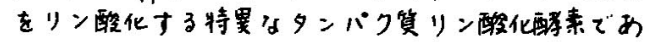
る.しかし、最近：亡の醉素が细胞膜上の情報变换 に重要な役制をもつイノシトールリン脂筫をもリン

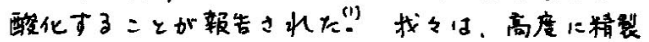

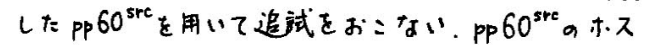
ファチジルイノシトール(PI)キナービ活性を磈詪し、

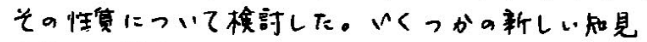
も含めて丕告する。

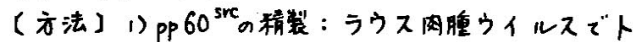
ランスフォームしたニクトリ㗏绵维芽细胞のTritonX100 抽出液より、カゼィンアがロース，千ロシンア ガロースアフィニティークロマトグラフィーによって精然

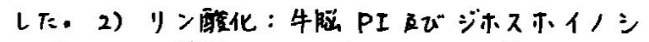

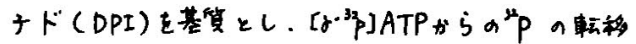
を调べた。

〔结果)右因(A)は、PP $60^{\text {src }}$ の P Iキナーゼ活性を 亦す、薄属りロマトのオートラジオグラムである。

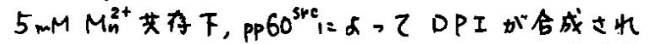

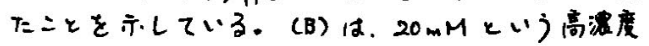

$M_{n}^{2+}$ 中では、DPIのリン酸化 (TPI合成) 酸素d

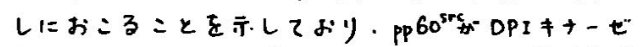

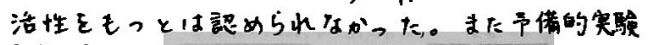

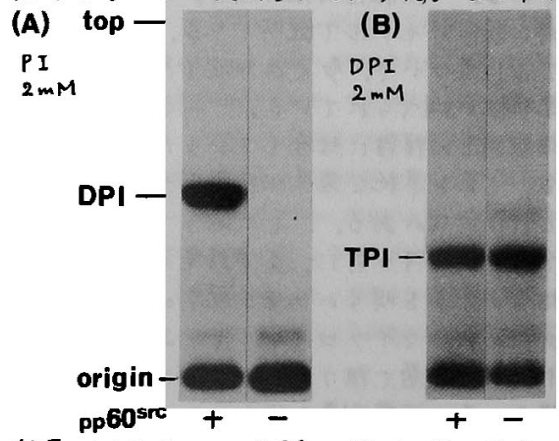

结果ではみるが、Pp60 sre のPIリン酸化反応の可迸性 が示唆された。昨年報告しえシビレエイのアセチル

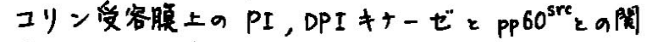

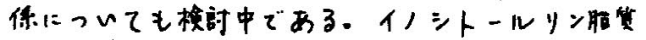

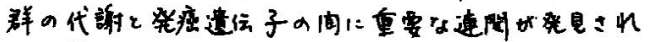
た意着は大きい。

(1) MarX, J. L. (1984) SCIENCE, 224, $271-274$. 


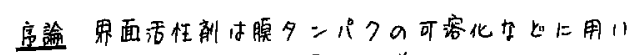
らん、㯖研究になける重要性が增している。我几は

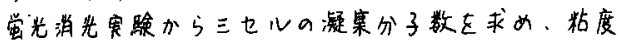
制定丸ら三セルの有效体樍を求のて三セルの水和の

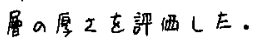

宝路界面性剠はオクチルグルコ三ド(OG)を用い E。(1)常光强度の测定からOGの臨界三セル濃度CMC

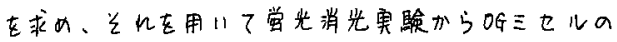

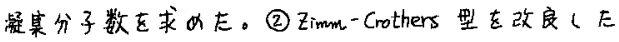

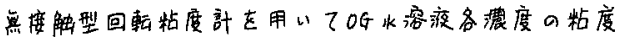

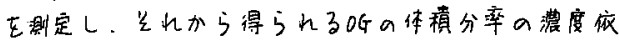
存性から三セルの有效体積を求のた。

結里と考察 (1)セルa疑基分子数の测定：ピレン

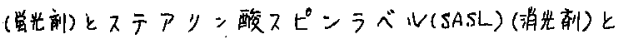
OF水溶变a混合夜a觉光强度を测足(

$\left(1-I / I_{0}\right)([O G]-C M C)=n[S A S L]$

1 : 定常光励起心よ子常光㤝度 $I_{0}$ : 静的党光强度 、式から三セルの凝集分子数んは90kなった。(四) (2) OG a粘度：OGは各濃度七もこュートン就動を示した。

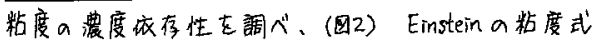

$\eta=\eta_{0}(1+2.5 \phi) \quad \gamma_{0}$ : 溶媒 $($ 水) a粘度 $\eta$ : 浚痤 a粘度 $\phi$ : 溶質(OG) a体棈分率

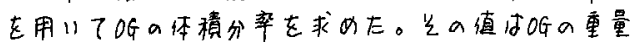
から予想される体䅧分率より約2.33 倍大きいことが

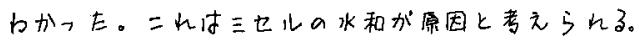
水和の屡の厚亡：まず水を含ます川三セルの大きを

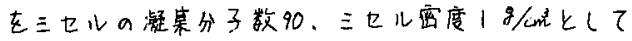
計算すると、半径が約 $22 \AA$ 上なる。水和を含中ると

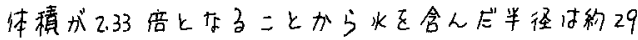

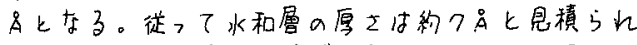
る。二の值时皆二重膜が $10 \AA$ 程度の水和を持つと 言われるのとよくー致する。
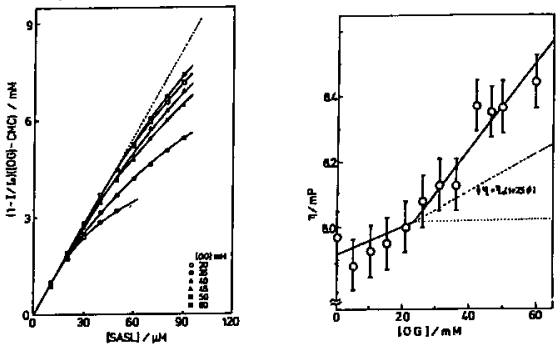

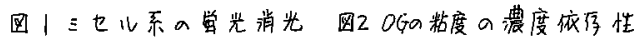

2E 1630

\section{霓气的脱刺礉による稩肥融合}

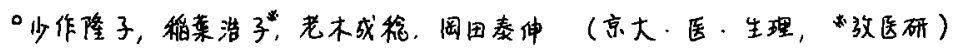

細胞膜間に高電圧パルスをかけ稩胞融合を引き起

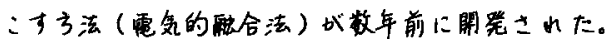
その後の我々の研究で次,渚点が明らかにす、た。

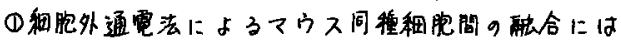

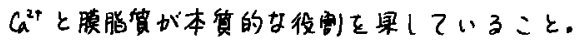
(2)蛋白分解醂素活性により著しく融合は促進される こと。(3)勫胞内通電法によ、了も稩胞融合が可能

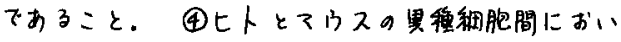
て比较的収率よく電统的融合が建成されうること。 むどである。

アウン・リンバ系白血病細胞( L5178Y) を前電泳

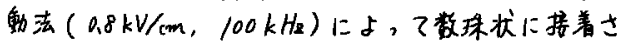
せた俊に、細胞外より高電圧パルス通電 $(5-8 \mathrm{kV} / \mathrm{cm}$.

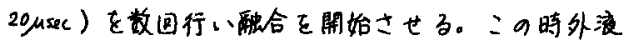
中のイオン辒成を变化させたところ、融合来は $\mathrm{Na}^{+}$，

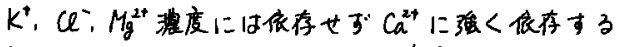
ンとが明らかとむ，た。また，蠤合率は温度にも强 く依存しろしニウス模プロットで不連镜性を示し，

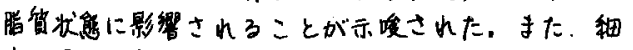

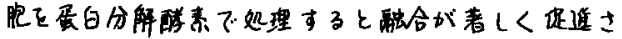

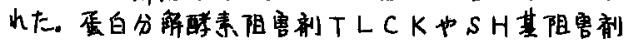

NEMで虽含曰抑制を受けた。

L5178Y a mutant である MCN15/稩胞と、ヒトロリ之

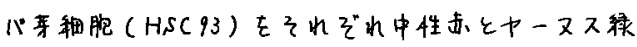
で生体染色した上で雨氛的融合を行巾せた。二の時 マウス間の同種勫胞間の融合は容易であ、たが、七 卜間の木乇かリオンやヒト・マウス間のへテロカリ オンの形成は，通電時に勫胞間9反発が和らる二

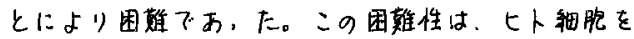
ノイラミニダーゼで前処理することによりかすり降 消され，此較的收率よくヒト、アウス間のへテロ力 リオンが得られることが判明した。

ギャップジャンクションの形成を行のないことの

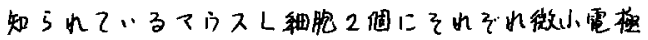
を剩入し，获械的に稩胞を接着させた徣に2本の電 极間に通電を行，たとこ了，2细胞間に電気的力ッ

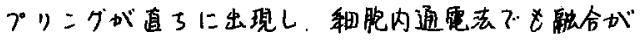
可能であることが示唆された。

昆気的融合法は条件を避へば $90 \%$ 近い高收率で

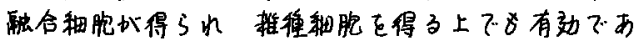
る。习た、融合メャ二ズムの解明にも新し、手段を 与えてくれるものと期待される。 
我マは，Protein-mediateな膜融合には蛋白の

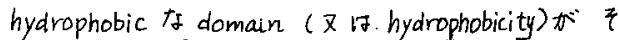

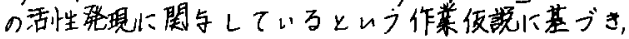
センダイウィルス，インフルエンザウイルスの䑏融

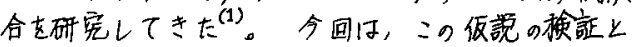
してメリチンによる egg PC sonicated vesicle の膜 融佮活性をスピンラベル法により研究した。

メリチンは，26価のアミ/酸よリ成る，amphipathic な水容性 peptide であり，分子中䄪70\% o hydrophobic domain.を持っている。Nativeなメりチンのみなら す，Succingl 化したメりチンの膜触合活性をも研究 しインフルエンザウイルスの酸性での㷬融合活性 上の関係下注目した。

メリチンは、Sigma社のものを使用し，精製及び Succingl化は, Belloらの方法 ${ }^{(2)}$ に従った。

\section{《結果》}

(1) Nativeなメリチンは，中性〜弱丁ルカリ性 ( pH 6〜9)に7膜融合活性女持つ。

（2）Succingl化メリチンは，中性〜了ルカリ性で の活性汀全く無くなり，弱酸性(PH 5.2〜5.3)

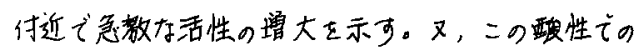
融合活性はNativeなメリチンのそれよりも大きく，

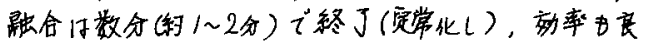
i.

（3）一度，膜融合活性が定常化(完了)した系に，新し く vesicleを加えても，それ认上の融合はおこらな い.しかし，新しくメリチンを加えると、らに触 合ねおこる。

(4) Sucinul 化メリチンは，膜融合活性のない中性

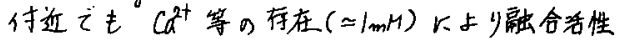
を持つようになる。

(5) 膜融合の際には，内容物のleak が短察され 万。

等，Native 及び Succinyle化 メリタンに特徵的九共通点， 相逜点がいつが胃られる。
1) S. B. Sato, et al. Proc. Natl. Acad. Sci. USA.,80, 3/53-3157 ('83)
2) Bello, J., et al. Biochemistry, 21, 461-465 (82)

2 E 1700

大䐎菌方らの统

一えの特性と resinの影算

东崎久婎（事北大，费研）

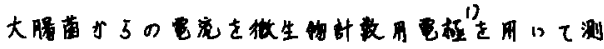

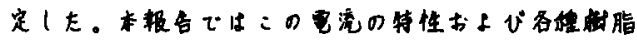

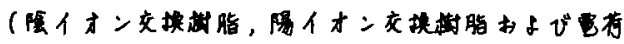

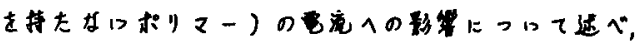

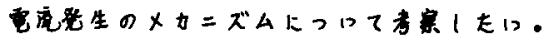

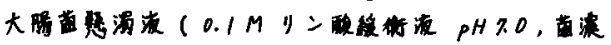

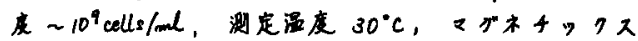

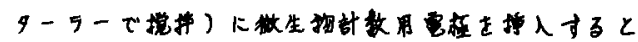

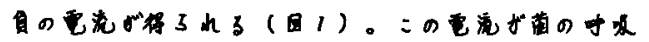

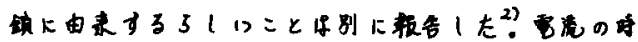

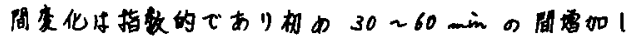

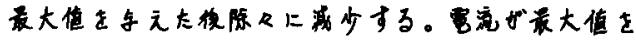

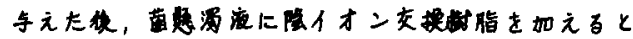

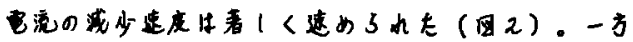

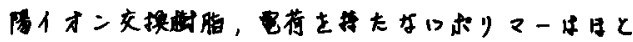

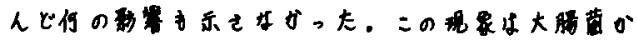

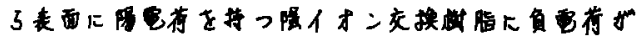

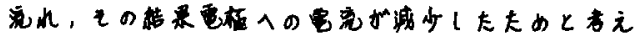
万人る。

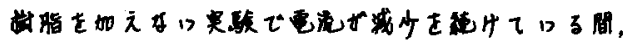

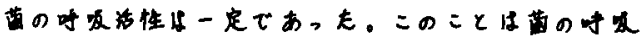

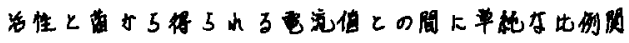

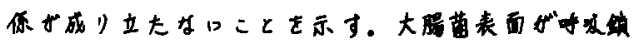

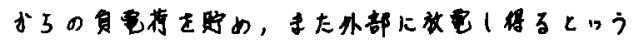

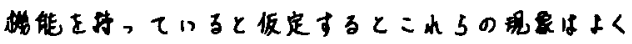
理解される。

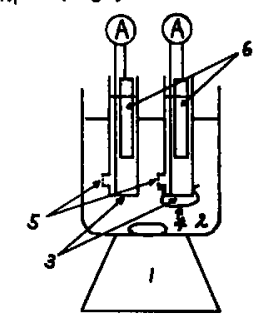

01

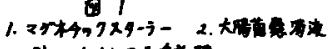

3. Pt $4 . t x 0-x$ ator

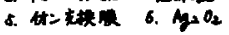

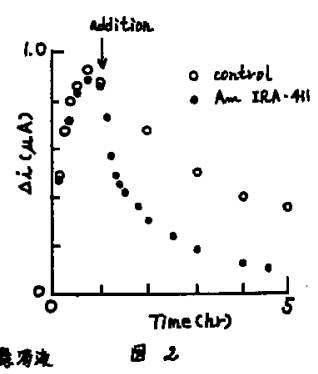

lit.

1) T. Matsunage A. al., Appl. Exvirom. Miesobiol,

2) H. Morisaki, J. Atu. Apl. Microbiol., 28,73 (1982). 


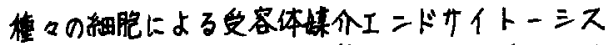
では，ホルモン精夕ンバ货・ウイルス等のりが ンドがCoated pitから取り込まれ，エンドリームによ って䋖脆内を通はれる。:のエンドソームは、勫胞 内输送の狳上で，内部酸性化，䅦成分子のソーテ ング，受容体のクサイクリング表の变化を起こしな がら、一次りソソームと融合し二次リソソームとな る。:の小跑による細胞内物寊输送は，尔胞楼能上 非常に重要でおり，我、は:の㭖模を解明するたの、 フェライト徝䊉子をエンドサイトーシスのりがンドと し、高磁場勾涀分画法によて：ニのリガンドを敢

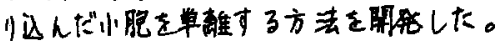

アシアロ不ツインを結合さ世份枚させたスライト

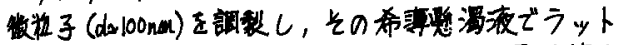

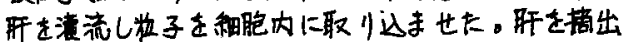
し、ホモジナイズ位、核、形真摸等を袁心で除き， 小坨を含大上清分画を高磁場(-20,000G)存在下で．磁

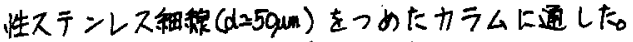
フェライトを含む小胞は緭稳に引き寄せられるが，他 は素通りし、クガンドを合む小胞が祄に得られた。

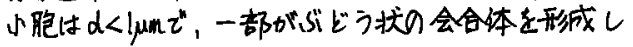

乙いた。

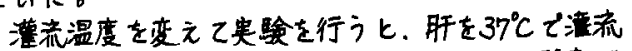
して得られたものは、リソンームのマーカー酤素で わ酸性有スファターゼやßーガラクトシダーゼ湖生が

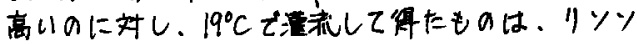
一ム磷表の㵇生は着しく低かた。耐者のタンバク

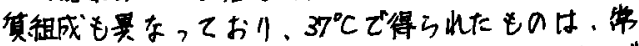
法で得大相りソソームと似ているのに对し，190 $\mathrm{C} て ゙$

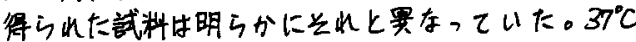
では，エンドリームはー次りソソームと融合しりが ンドは二次りソリームまで連ばれるのに祄し，低温 $\left(19^{\circ} \mathrm{C}\right)$ では融出が物制され、グンドはエンドリーム

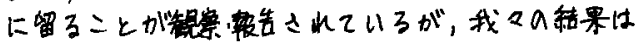
この考えを支持する。

高磁境勾配分画法は当然他のりがンド、初胞系に も透用可能でのり、特定のりがンドを合む小脃を。 煩䑾子透心操作を必要と世ずに高絍度に分而できる。 また小胞の大ミミ密度がばらついていても回収可能 でんク、敞子の利も原理的に可能である。不ライ

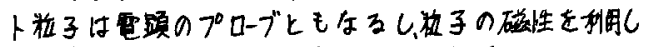
稩肥枚能を新側面から研究できる可能性がある。

2F 0930

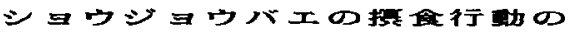

$$
\begin{aligned}
& \text { シミユレーシミン } \\
& \text { 田一郎 }
\end{aligned}
$$

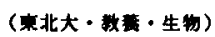

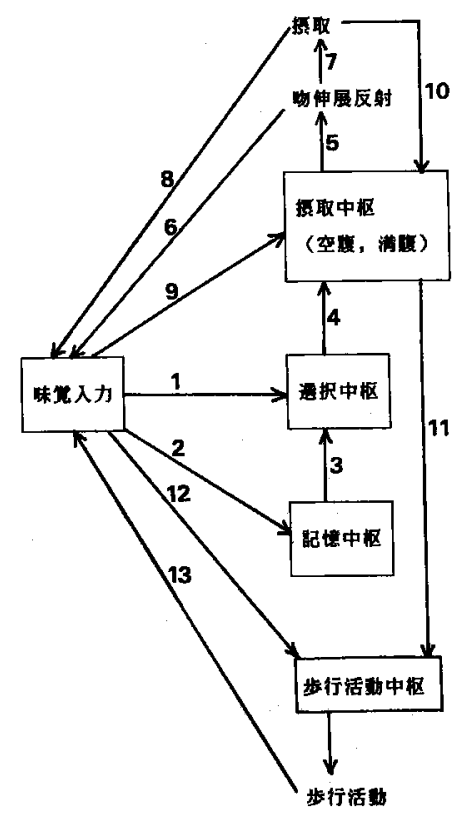

